\title{
Sağlık Kurumları İşletmeciliği Programlarının Ders Çeşitliliğinin Analizi
}

\author{
Hale ERSAN \\ Uşak Üniversitesi \\ hale.ersan@usak.edu.tr \\ ORCID ID: 0000-0002-7042-3186 \\ İbrahim TÜRKMEN \\ Uşak Üniversitesi \\ ibrahim.turkmen@usak.edu.tr \\ ORCID ID: 0000-0002-1558-0736 \\ Ramazan Rüçhan KAYA \\ Uşak Üniversitesi \\ ramazan.kaya@usak.edu.tr \\ ORCID ID: 0000-0001-6520-1848
}

Araştırma Makalesi

Geliş Tarihi: 29.10.2020

Revize Tarihi: 29.10.2021

DOI: $10.31592 /$ aeusbed.818012

\section{Atıf Bilgisi}

Ersan, H., Türkmen, İ. ve Kaya, R. R. (2021). Sağlık kurumları işletmeciliği programlarının ders çeşitliliğinin analizi. Ahi Evran Üniversitesi Sosyal Bilimler Enstitüsü Dergisi, 7(3), 792-809.

\section{ÖZ}

Sağlık Kurumları İşletmeciliği ön lisans programları, sağlık kurumlarının orta ve alt düzey idari pozisyonları için profesyonel insan kaynağı yetiştirmek üzere faaliyet göstermektedir. Bu araştırmayla Türkiye'de önlisans düzeyinde eğitim vermekte olan Sağlık Kurumları İşletmeciliği programlarının güncel ders programlarında yer alan ders çeşitliliği incelenerek, bu programlardan yetişen mezunların aldıkları dersler açısından yetkinliklerinin ortaya çıkarılması hedeflenmektedir. Araştırma, Sağlık Kurumları İşletmeciliği programlarında müfredat geliştirme çalışmaları için yol gösterici olması ve sağlıkta insan kaynakları planlaması üzerine öneriler sunması açısından önemli görülmektedir. Araştırmada ikincil verilerden yararlanılmış, bu kapsamda YÖK önlisans atlası ve üniversitelerin Bologna bilgi paketleri kullanılmıştır. Araştırma kapsamında Sağlık Kurumları İşletmeciliği programı bulunan ve örgün eğitim vermekte olan 34 devlet, 14 vakıf olmak üzere 48 üniversite tespit edilmiştir. Gerekli verilere ulaşlamayan 12 üniversite örneklemden çıkarılmış, 26 devlet ve 10 vakıf olmak üzere 36 üniversitenin Sağlık Kurumları İşletmeciliği programlarının müfredatında yer alan derslerin çeşitliliği incelenmiştir. Araştırma sonucunda Türkiye'de Sağlık Kurumları İşletmeciliği programlarında ders sayılarının 24 ile 70 arasında çok geniş bir aralıkta değiştiği tespit edilmiştir. Devlet üniversitelerinde ortalama 36 ders bulunurken vakıf üniversitelerinde ortalama 40 ders bulunmaktadır. Devlet üniversitelerinde daha çok zorunlu dersler, vakıf üniversitelerinde ise daha çok seçmeli dersler bulunmaktadır. Sağlık Kurumları İşletmeciliği programları müfredatlarında yer alan 196 ders tespit edilmiştir. Söz konusu derslerin, içerikleri ve kapsamları incelendiğinde; "sağlık bilimleri, hukuk, matematik, ekonomi ve finansman, sosyoloji, yönetim ve strateji, iletişim, teknoloji, araştırma yöntemleri, mesleki uygulama, sanat, mesleki İngilizce, beden eğitimi, psikoloji, işletme, pazarlama, kalite, dokümantasyon” olmak üzere 18 farklı alan içerisinde değerlendirilmişlerdir. Bu durum Sağlık Kurumları İşletmeciliği mezunlarının başta yönetimsel dersler olmak üzere, sağlık bilimleri, ekonomi ve hukuk gibi önemli alanlarda dersler aldıklarını ve sağlık kurumlarının ilgili idari birimlerinde görev alabilecek yetkinlikte olduklarını göstermektedir. Anahtar Kelimeler: Sağlık Kurumları İşletmeciliği, Sağlık Yönetimi, Bologna, Müfredat, Üniversiteler, İnsan Kaynakları Yönetimi.

\section{Analysis of Course Diversity of Management of Health Instituations Programs}

\begin{abstract}
Management of Health Instituations associate degree programs operate to train professional human resources for middle and lower level administrative positions of health health facilities. With this research, it is aimed to examine the variety of courses included in the current curriculum of Management of Health Instituations programs that are providing associate degree education in Turkey and to reveal the competencies of graduates who are trained in these programs in terms of the courses they receive. The research is seen as important for guiding curriculum development in Management of Health Instituations programs and providing recommendations on human resource planning in health. Secondary data was used in the study, and in this context, the associate degree atlas of YÖK and the Bologna information packages of universities were used. Within the scope of the research, 48 universities were identified, including 34 public universities and 14 foundation universities, which have Management of Health Instituations programs and provide formal education. 12 universities that did not have the necessary data were removed from the sample and the variety
\end{abstract}


of courses included in the curriculum of Management of Health Instituations programs of 36 universities consisting of 26 public universities and 10 foundation universities was examined. As a result of the research, it was found that the number of courses in Management of Health Instituations programs in Turkey varies from 24 to 70 in a very wide range. Public universities have an average of 36 courses, while foundation universities have an average of 40 courses. Compulsory courses are more common in public universities, and elective courses are more common in foundation universities. 196 courses included in the curricula of Management of Health Instituations programs have been identified. Examined the content and scope of the courses in question; "health sciences, law, mathematics, economics and finance, sociology, management and Strategy, Communication, Technology, Research Methods, Professional Practice, Art, English, vocational, physical education, psychology, business, marketing, quality, documentation" fields, including 18 different areas were evaluated. This indicates that graduates of the Management of Health Instituations program take courses in important areas such as health sciences, economics and law, especially management courses, and are competent to work in the administrative units of health institutions.

Keywords: Management of Health Instituations, Health Management, Bologna, Curriculum, Universities, Human Resources Management.

\section{Giriş}

Günümüzde küreselleşmenin de etkisiyle yaşanan gelişmeler toplumsal, ekonomik, sosyal, kültürel ve teknolojik alanlarda hızlı bir değişim yaratmaktadır. Bu hızlı değişim özellikle bilim ve teknoloji alanında kendini göstermektedir. Geçmişte sanayi devriminin etkisiyle meydana gelen bu değişim, günümüzde bilgi ve iletişim teknolojilerindeki gelişmeler ile devam etmektedir (Aktan ve Vural, 2016, s. 2). Yaşanan değişim neticesinde içinde bulunduğumuz bilgi çağının bir gereği olarak hem toplumsal hem de ekonomik yapı dönüşmekte, toplumsal yap1 için "bilgi toplumu" ekonomik yapı için ise "bilgi ekonomisi" adında yeni bir anlayış ortaya çıkmaktadır. Buna göre insanların sahip oldukları bilgi düzeyleri insani gelişmişliklerini (eğitim, sağlık ve gelir) belirlemekte; ülkeler açısından ise kalkınmışlık ve rekabet gücü ise sahip oldukları entelektüel sermayeleri ile ölçülmektedir (Yükseköğretim Kurulu [YÖK], 2007, s. 13).

Ülkelerin gelişmişlik düzeylerini etkileyen; üretme, gelişme ve kalkınma çalışmalarının temelini oluşturan, değişime yön veren ve gelecek için yapılan en önemli yatırım eğitimdir (Güneş, 2012, s. 1). Eğitim kurumları, ülkelere bu beşeri ve sosyal sermayeyi kazandıran en önemli kurumlardır. Eğitim kurumları ülke ekonomilerini geliştirirken ekonomik anlamda fayda sağlamalarının yanında, entelektüel sermayenin geliştirilmesi fonksiyonunda da etkili rol oynayan kurumlardır. Bu fonksiyonların gerçekleştirilmesinde yükseköğretim kurumlarının katkısı oldukça yüksektir. Aynı zamanda yükseköğretim kurumları kuruldukları bölgelerde hem sosyal hem de ekonomik gelişime fayda sağlar. Bu durum ilerleyen süreçte ülke geneline yayılır (Dalğar, Tunç ve Kaya, 2009, s. 40).

Türkiye'de yükseköğretime olan talep gelişmekte olan diğer ülkelerde olduğu gibi giderek artmaktadır. Bu sebeple artan talebi karşılamak adına yükseköğretim kurum sayısı gün geçtikçe artarken, hâlihazırda eğitim veren kurumların da eğitim kapasiteleri arttırılmaktadır. Genç nüfusun ülkemizdeki yoğunluğu ve demografik değişimi sebebiyle yükseköğretim kurumlarına olan talebin artmaya devam edeceği görülmektedir (Günay ve Özer, 2016, s. 2). Yükseköğretim kurumları içinde, özellikle sanayi, ticaret ve hizmet sektörlerinde yer alan iş dünyasının ihtiyaç duyacağı alt ve orta düzey personelin yetiştirilmesi maksadıyla kurulan meslek yüksekokulları, mesleki ve teknik eğitimin en önemli unsurudur (Alkan, Suiçmez, Aydınkal ve Şahin, 2014, s. 134). Meslek Yüksekokullarında verilen mesleki eğitimle, bu eğitimi alan bireyler sektörün beklentilerini karşılayacak gerekli donanımı kazanırlar. Meslek Yüksekokullarından mezun olanlara tekniker/ meslek elemanı unvanı verilir. Bu unvana sahip olan kişi, çalıştıkları/çalışacakları kurumlarda nitelikli ara personel ihtiyacını karşılamaktadır (Kaya, 2014, s. 348).

Mesleki ve teknik eğitimin işgücü piyasasında talep edilen belirli özelliklere göre güncellenmesi ile özellikle gelişmekte olan ülkelerdeki yüksek işsizlik oranları ve istihdam uyumsuzluğu sorunu azaltılabilmektedir (Eichhorst, Rodriguez-Planas, Schmidl, ve Zimmermann, 2012, s, 1). Mesleki-teknik eğitimin bir parçası olan Meslek Yüksekokullarının eğitim kalitesinin yükseltilmesi, verilen eğitim ve istihdam olanakları dengesinin sağlanması ülkenin kalkınması ve rekabet gücünün artırılması bağlamında büyük önem arz etmektedir ve bu bağlamda kalkınma planları 
içinde önemli bir başlık olarak yerini almıştır (Günay ve Özer, 2016, s. 2). Meslek yüksekokulları içerisinde sağl1k hizmetlerine yönelik eğitim veren kurumlar bu sebeple son yıllarda özellikle istihdam kapsamında ön plana çıkmaktadır.

Günümüzde gelişmiş ülkelerde olduğu gibi Türkiye'de de tıbbi teknolojilerin ve mesleki bilgi birikiminin artmasıyla birlikte sağlık hizmetleri gelişmektedir. $\mathrm{Bu}$ gelişmeler sonucunda sağlık hizmetlerinin çeşitliliği artmış ve yeni sağlık meslekleri ortaya çıkmıştır. Ortaya çıkan bu mesleklere yönelik yeni iş ve görev tanımları yapılmış ve bu durum sağlık sisteminin "nitelikli sağlık insan gücü" ihtiyacının artmasına neden olmuştur. Bu insan gücünü karşılamak amacıyla "Sağlık Meslekleri Eğitimi” verilen Sağlık Hizmetleri Meslek Yüksekokullarının mezunları, sağlık sektörünün vazgeçilmez unsurları olmuştur. Buradan mezun olan kişiler verilen hizmetlerde kalite ve katma değer yaratmakta, tıbbı teknik altyapıyı etkili şekilde kullanarak sağlık hizmetlerinde hekimlere destek sağlamaktadır. Dolayısıyla bu okullardan mezun olan sağlık teknikerlerine verilen önem ve ihtiyaç her geçen gün artmaktadır (Taştan, 2017, s. 2).

\section{Sağlık Kurumları İşletmeciliği Eğitimi}

Sağlığın insan hayatındaki konumu, ortak kabul etmeyecek şekilde önemlidir. Bu konuda Kanuni Sultan Süleyman'ın sağlığın önemi ile ilgi söylediği; "Halk içinde muteber bir nesne yok devlet gibi, olmaya devlet cihanda, bir nefes sıhhat gibi" sözü herkesçe bilinmektedir. Aslında bu söz sağlığın öneminin devletin varlığıyla aynı seviyede tutulduğu, diğer bir deyişle sağlığın devlet gibi büyük bir otoriteye eş değer görüldüğ̈̈ bir söylemdir.

Sağlık hizmetleri sunumunda en önemli faktör hekimlerdir. Hekimler, tıp biliminin icrasının onlara vermiş olduğu tıbbi güç (Turner, 2011, s. 45) ve otorite sebebiyle saygınlığı tartış1lmaz bir mesleğe mensuptur. Bu durum geçmişten günümüze hekimleri sağlık hizmet sunumun gerçekleştiği tüm kurumlarda doğrudan lider konumuna getirmektedir. (Akdaş, Sur, Şişman ve Gemlik, 2008, s. 41). Mintzberg (1979, s. 348), hastaneler gibi sağlık kuruluşlarında profesyonel bürokrasinin geçerli olduğunu ifade etmektedir. Dolayısıyla hekimlerin resmi olarak yönetici olmadıkları hallerde dahi sağlık ekibi içerisinde, mesleki bir ağırlıkları olduğu ve lider olarak değerlendirildiklerini söylemek yanlış olmayacaktır.

Günümüzde hastanelerin yönetim kademelerinde hekimlerin yer aldığı görülmektedir. Hekimlerin tıp eğitimi sırasında yönetimsel süreçlerle ilgili yetiştirilmediği düşünüldüğünde, hekimlerin yönetimindeki sağlık kurumlarının bazı yönetimsel sorunlarla karşılaşması muhtemeldir (Sur, 2017). Hekimlik başlı başına bir sorumluluk ve asli görevleri olmasına rağmen yöneticilik görevleriyle de ilgilenmeleri mesleki kimliklerini melezleştirmekte hekimlik ile yöneticilik arasında kalmalarına sebep olmaktadır (Joffe ve MacKenzie-Davey, 2012, s. 171; Kippist ve Fitzgerald, 2009, s. 644; Spehar, Frich ve Kjekshus, 2014, s. 2). Dolayısıyla hekimlik mesleğinin yanı sıra ekstra bir yük olarak yöneticilik yapmaları hekimleri mesleki anlamda bir karmaşaya sürükleyecek belki de körelmelerine sebep olacaktır (Kaya ve Kaya, 2021, s. 290). Her ne kadar yönetim konusunda bir eğitim almamış olsalar da hekimler, sağlık kurumlarında yönetim kademelerinde yer almak için bir eğitime gerek olmadığını düşünmektedirler, Nusret Fişek (1968), bu konuda hekimlerin yönetimi bir bilim olarak kabul etmeleri gerektiğini vurgulayarak bu durumu; "Hekimler yönetimin bir bilim olduğunu kabul etmezlerse ve sağlık yönetiminde görev alanlar yönetim bilimini öğrenmez, yönetim uzmanlarının önerilerini dinlemez ve yönetim kurallarını uygulamazlarsa, hizmetlerini geliştiremezler" şeklinde ifade etmiştir. Bu görüşten yola çıkılarak, sağlı yöneticiliği için bu konuda özel yetişmiş olmak gerektiğini söylemek yanlış olmayacaktır (Sarvan, 1995, s. 12).

Sağlık kurumları, dinamik, değişken ve açık sistemlerdir (Tengilimoğlu, Akbolat ve Işık, 2018, s. 192). Ayrıca sağlık hizmetlerini sunmalarının yanı sıra birer işletme olmaları sebebiyle bilimsel işletmecilik yöntemlerinin de göz önünde bulundurulması gereken kompleks yapılardır (Kavuncubaşı ve Yıldırım, 2015, s. 96). Dolayısıyla sağlık kurumlarında yönetimsel faaliyetler, sevk zinciri, örgütlenme, personel, finans, donanım ve bilgi sistemleri kaynaklı problemlerin çözülmesi (Ersoy ve Kavuncubaşı, 1995, s. 7; Türk Tabipleri Birliği [TTB],1995, s. 153) gibi kurum amaçlarının 
etkili ve verimli şekilde gerçekleştirilmesi adına gerek üst düzey gerekse orta ve alt düzey yönetim kademelerinde profesyonel sağlık yöneticilerine ihtiyaç duyulmaktadır.

Sağlık yönetimi anlayışının temelleri 20.Yüzyılın başlarında Amerika Birleşik Devletleri’nde atılmış ve hastane yöneticiliği adı altında uzmanlık eğitimi verilmeye başlamıştır. Sağlık yönetiminin bir bilim dalı olarak Türkiye'ye gelişi ise 1963 yılında Sağlık ve Sosyal Yardım Bakanlığı bünyesinde Sağlık İdaresi Yüksekokulu'nun kurulmasıyla gerçekleşmiştir. (Sarvan, 1995, s. 12). 2018 yıl1 itibariyle Türkiye'de 75'i önlisans, 93'ü lisans, 50'si Yüksek Lisans ve 13'ü Doktora düzeyinde olmak üzere çeşitli üniversitelerde sağl1k yönetimi eğitimi verilmektedir (Tengilimoğlu vd., 2018, s.568).

Türkiye'de ön lisans düzeyinde sağlık yönetimi eğitimi, meslek yüksekokulları bünyesinde yer alan "Sağlık Kurumları İşletmeciliğì" programlarında verilmektedir. Charles Austin, sağlık yönetimini tanımlarken; "...tıp ve sağlık hizmetlerinin tüm boyutlarını işletmecilik perspektifiyle inceleyen, uzmanlaşmış yönetsel disiplin” şeklinde ifade etmiştir. Ancak gerek bu tanımdaki gerekse Türkiye'de yer alan sağlık yönetimi alanında eğitim veren ön lisans programların isimlerinde yer alan işletmecilik kavramı; serbest piyasa koşulları, rekabet ve karlılık ifadesi olarak değil sağlık kurumlarında kaynakların etkin ve verimli yani ussal kullanımını vurgulamaktadır (Kavuncubaşı ve Yıldırım, 2015, s. 5). Bu doğrultuda sağlık kurumlarının herhangi bir işletmeden farklı olarak, kar yüksekliğine değil insan hayatına odaklandığını vurgulamak gerekmektedir.

Türkiye'de Sağlık Kurumları İşletmeciliği ön lisans programlarında:

- Sağlık yönetimi hakkında temel bilgilere sahip,

- Sağlık alanındaki güncel bilgileri takip ederek kararlarında kullanabilen,

- Ülke ve Dünya gündemindeki sağlık politikaları ile ilgili bilgileri öğrenip, değerlendirebilen,

- Sağlık kurumlarıyla ilgili gerekli arşiv kayıtlarını tutabilen, gerekli yazışmaları takip edip yönetebilen,

- Hekimler ve diğer sağlik personelleri ile iş birliği içerisinde ve sorumluluk alarak çalışabilen,

- Sağlık kurumlarını ilgilendiren gerekli istatistiki bilgileri elde edip bu bilgileri yorumlayabilen,

- Sağlık kurumlarının mevzuatsal yapısını, kendisinin ve beraber çalıştığı diğer sağlık personellerinin hak ve sorumluluklarını bilen ve gerektiğinde kullanabilen,

- Ülkenin güncel sağlık sistemi ve politikaları çerçevesinde çalışabilen ve değişimlere ayak uydura bilen,

- Sağlık personellerinin yetiştirilmesi amaçlanmaktadır (https://tyc.gov.tr/).

Amaca uygun şekilde Sağlık Kurumları İşletmeciliği ön lisans programı mezunları:

- Sağlık Bakanlığı'nın merkez ve taşra teşkilatlarında,

- Kamu hastaneleri, Üniversite hastaneleri ve özel hastaneler gibi tüm hastanelerin idari birimlerinde,

- Sağlıkla ilgili rehabilitasyon hizmeti sunan merkezlerde,

- Özel sağlık sigortası kuruluşlarında,

- İlaç ve tıbbi cihaz üreten kurumlarda,

- Sağlık araştırmaları yapan kurumlarda,

- Diyaliz merkezlerinde,

- Diğer özel ya da gönüllü sağlık hizmeti sunan kuruluşlar vb.,'inde çalışabilecek gerekli bilișsel yeterliliklere sahip olarak yetiştirilmekte ve istihdam olanağı bulunmaktadır (https://tyc.gov.tr).

$\mathrm{Bu}$ doğrultuda Sağlık Kurumları İşletmeciliği programları, yetiştireceği insan profili gereği üzerine düşen misyonla, sağlık kurumlarının işleyiş̧inde önemli bir yer aldığı söylenebilir. Dolayısıyla bu programlarda verilecek eğitimin içeriği son derece önem arz etmektedir. 


\section{Yükseköğretimde Bologna Süreci}

Kalkınmışlık düzeyinin yükselebilmesi için yükseköğretim kurumlarının; sorgulayan, analitik ve eleştirel düşünme becerisine sahip, çözüm odaklı, araştırmacı kişiliğe sahip, anlama kapasitesi yüksek bireyler yetiştirmesi kritik öneme sahiptir. Teknolojiye ve bilimsel gelişmelere uyum sağlayamayan ezberci, kalıplaşmış yargılar barındıran geleneksel eğitim anlayışı, modern bilgi toplumunun beklentilerini karşılayamamaktadır. Bu durumun ülkenin gelişimine katkı sağlamadığını gören bazı ülkeler, yükseköğretimde eğitim sistemi üzerinde değişiklikler yapmaya başlamıştır (Güneş, 2012, s. 1). Bu anlamda dünyanın pek çok farklı yerinde yoğun çalışmalar yürütülmektedir. Yapılan çalışmaların ortak noktası eğitimin girdilerden ziyade öğrenim çıktılarının geliştirilmesi ve kalitesinin artırılmasına yöneliktir (Elmas, 2012, s. 138).

Avrupa ülkelerinin neredeyse tamamı, 1990'larda ve 2000'li yılların başında idari ve mali konularda kendi yükseköğretim sistemlerinin sorunlarına çözüm bulmak amaciyla yasal düzenlemeler yapmışlardır. Burada ortaya çıkan ortak sorun Avrupa ülkelerinin farklı üniversite geleneklerinin olmasidır (YÖK, 2007, s. 28). Bununla ilgili olarak 1998 yılında, başta Fransa olmak üzere İngiltere, Almanya ve İtalya'nın katılımılla yapılan Sorbonne'daki toplantıda, ortak bir "Avrupa Yükseköğretim Alanı (AYA)" oluşturma fikri ortaya çıkmıştır. Avrupa'nın yükseköğretim sistemlerinin daha çekici, daha rekabet edebilir ve Avrupa yükseköğretim mezunlarının daha fazla 'istihdam edilebilir' olması amaçlanmış (Wachter, 2004, s. 265) ve buna binaen bir yıl sonra Bologna'da Avrupa'dan 29 ülkenin katılımıyla, Avrupa'da yükseköğretimde "ortak bir alan” oluşturmak amacıyla Bologna Bildirisi imzalanmıştır. Yükseköğretimde öğrenciler ile birlikte öğretim elemanlarının da hareketliliğini yaygın hale getirerek Avrupa'nın yükseköğretimde etkinliğini arttırmak, yükseköğretim derecelerinin ve diplomalarının birbiriyle eşdeğer, karşılaştıılabilir ve anlaşılır olmasını sağlamak, Avrupa Kredi Transfer Sistemini uygulamak, kalite güvencesi ile ilgili sistemler oluşturup uygulamak Bologna sürecinin hedefleri arasındadır. Bugün bu süreç yalnızca Avrupa'dan değil, farklı kıtalardan pek çok farklı ülkenin de sürece dâhil olması ile birlikte 47 üye ile devam etmektedir (Çelik, 2012, s. 101).

Türkiye'nin Bologna sürecine katılımı 2001'deki Prag toplantısında gerçekleşmiştir. Türkiye bu süreç ile yükseköğretimde dünyadaki yerini ortaya koymak istemiştir. Türk Ulusal Ajans1, Türkiye'deki süreç çalışmalarını değerlendirmek için Bologna Rehberleri Ulusal Takımını kurmuştur. Türkiye, bu süreçte performansını izleyerek ara değerlendirmelerle yükseköğretimde kaliteyi arttırmayı hedeflenmektedir. Yapılan performans değerlendirmesi sonucu 2005-2007 arası Türkiye'nin performansı Bologna ülkelerinin ortalamasının üstünde gerçekleşmiştir ve bu durum oldukça olumlu karşılanmıştır (Arslan ve Bahadır, 2007, ss. 222-229).

Bologna süreci ile yükseköğrenimde üç aşamalı bir sisteme geçilmiştir. Bu sistemde ilk aşama lisans (3-4y1l), ikinci aşama yüksek lisans (2 y1l) ve üçüncü aşama doktora (4 yıl) olarak belirlenmiştir. $\mathrm{Bu}$ aşamalar için Avrupa Kredi Transfer Sistemi (European Credit Transfer System [ECTS/AKTS]) dâhilinde gerekli krediler belirlenmiştir. Türk Yükseköğretim Sistemindeki "önlisans" yani "kısa dönem” dereceleri 2005 Bergen Bakanlar Zirvesinde (Avusturya), yükseköğretimin birinci aşamas1 içerisinde tanımlanmıştır. Ön lisans dereceleri, öğrencilerin ortaöğretimde mesleki olan veya olmadan aldıkları eğitimden hemen sonra meslek edinmelerini sağlamayı ve bunu insan kaynakları çeşitliliğini arttırarak gerçekleştirmeyi hedefler. Ön lisans düzeyi daha çok ara düzey personel yetiştirmeye yöneliktir ve bu düzeyde gereken nitelik ve yeterlikler sektörlerle işbirliği içinde, ilgili sektördeki değişmelere duyarlı ve hızlı şekilde cevap verecek nitelikte planlanmaktadır. Bu niteliklerin tespit edilmesinde ve planlanmasında yer alan "düzey tanımlayıcıları ve öğretim çıktıları" kısa dönemli derecelerde 120 AKTS kredisi olarak belirlenmektedir (YÖK, 2007, s. 30).

Bologna süreci ile birlikte 2005 yılında Bergen'de yapılan Bakanlar Zirvesi ile ulusal yeterlilikler çerçevelerinin oluşturulması kararı alınmış, Türkiye de Yükseköğretim Kurulu tarafindan ilk çalışmalarını yükseköğretimde Ulusal Yeterlilikler Çerçevesi (UYÇ) oluşturulmasıyla başlatmıştır. $\mathrm{Bu}$ çalışmalarla birlikte Yükseköğretim Yeterlilikler Komisyonu (YYK) kurulmuş ve komisyon temelde UYÇ'yi, Avrupa Yükseköğretim Alanı Yeterlilikler Çerçevesi tanımlayıcıları dâhilinde önlisans, lisans, yüksek lisans ve doktora gibi yükseköğretimin tüm düzeyleri sonunda temel olarak 
edinilmesi gerekli olan yetkinlik, bilgi ve becerilere göre tanımlamıştır. Daha sonra komisyon çalışmaları ile birlikte Türkiye Yükseköğretim Yeterlilikler Çerçevesi (TYYÇ) oluşturulmuştur (YÖK, 2010).

TYYÇ'de ana başlıklar; sahip olunması beklenen bilgi "Kuramsal ve olgusal", edinilmesi gereken beceri "Bilişsel ve uygulamalı", kazanılması yetkinlikler ise "Bağımsız çalışabilme ve sorumluluk, öğrenme, iletişim ve sosyal yetkinlik, alana özgü yetkinlik" ifadelerinden meydana gelmektedir. (Elmas, 2012, s. 139). Burada yer alan yeterliliklerin içeriği, Sağlık Hizmetleri Meslek Yüksekokulları için "Sağlık" temel alanı içinde 5. Düzey (MYO) bölümünde ön lisans programları için ayrıca belirlenerek Sağlık Hizmetleri Meslek Yüksekokullarında eğitim gören her öğrenciye asgari olarak kazanılması gereken bilgi, beceri ve yetkinlikler geliştirilmiştir.

Bu çalışmada Türkiye'de eğitim ve öğretim faaliyeti gösteren devlet ve vakıf üniversitelerinin ön lisans düzeyinde eğitim veren Meslek Yüksekokulları içinde Sağlık Kurumları İşletmeciliği programlarının Bologna çalışmaları kapsamında belirlenen müfredatları ve verilen derslerin AKTS değerleri incelenmiştir.

\section{Yöntem}

Araştırma ikincil verilerden yararlanılan nicel bir araştırmadır. Araştırma kapsamında YÖK tarafından erişime açılmış olan YÖKATLAS veri tabanı kullanılmıştır (https://yokatlas.yok.gov.tr). YÖKATLAS Ön Lisans Atlası üzerinden Sağlık Kurumları İşletmeciliği programı aratılmış ve 2019 yılı itibariyle öğrenci almış bulunan üniversiteler ve programlar üzerinden araştırma yapılmıştır.

\section{Evren ve Örneklem}

Çalışmanın evreni, Türkiye'deki üniversitelerde yer alan Săglık Kurumları İşletmeciliği programlarından oluşmaktadır. Belirli bir örneklem seçilmeden evrenin tamamına ulaşılmaya çalışılmıştır. YÖKATLAS Ön Lisans Atlası üzerinden yapılan taramada, Türkiye'de Sağlık Kurumları İşletmeciliği programı bulunan 34 kamu ve 14 vakıf olmak üzere 49 üniversite tespit edilmiştir. Afyon Sağlık Bilimleri Üniversitesi ve Kayseri Üniversitesi'nin Sağlık Kurumları İşletmeciliği programlarının Bologna bilgilerine ulaşılamadığı için araştırma kapsamına alınamamıştır. Ayrıca açık öğretim sistemi üzerinden eğitim öğretim yapılan üniversite programları örnekleme dâhil edilmemiştir. Birden çok Sağlık Kurumları İşletmeciliği programı bulunan üniversitelere ait sadece bir program alınmıştır. Yapılan elemeler sonucunda 26 kamu, 10 vakıf üniversitesinin Bologna sistemleri üzerinden araştırma yapılmıştır.

\section{Verilerin Toplanması ve Analizi}

Sağllk Kurumları İşletmeciliği programlarının müfredatlarında yer alan derslerin; isimleri, saatleri, AKTS'leri, dönemleri, zorunlu/seçmeli durumları ve teorik/uygulama olarak ders çeşitliliği incelenmiştir. Üniversitelerin Bologna sistemleri üzerinden yapılan tarama sonucunda tespit edilen derslerin Zorunlu/Seçmeli olması durumu, Ders saatleri (Teorik/uygulama), AKTS bilgileri analiz kapsamına alınmıştır. Elde edilen veriler Excel programında oluşturulan veri tabanına aktarılarak frekans dağılımları değerlendirilmiştir. Ayrıca araştırma kapsamında tespit edilen dersler konularına, içerik ve kapsamlarına göre kendi aralarında gruplandırılarak, Sağlık Kurumları İşletmeciliği programlarının derslerinin kapsamı tespit edilmeye çalışılmıştır. Bu yöntemle Sağlık Kurumları İşletmeciliği mezunlarının elde etmiş̧ oldukları teorik yetkinlikler belirlenmesi ve istihdam olanaklarının değerlendirilmesi hedeflenmektedir.

\section{Araştırma Etiği}

$\mathrm{Bu}$ araştırma, Türkiye'de Sağlık Kurumları İşletmeciliği programı bulunan üniversitelerin, Bologna bilgi paketlerinden yararlanılan, ikincil verilerin kullanıldığ 1 bir araştırmadır. Araştırma kapsamında insan ya da hayvan öznesi bulunan; deney, gözlem, anket ya da mülakat yöntemleri kullanılmamıştır. Bu sebeple Etik kurul raporu alınmasına gerek duyulmamıştır. 


\section{Bulgular}

\section{Sağlık Kurumları İşletmeciliği Programlarının Toplam Ders Sayıları Açısından Değerlendirilmesi}

Sağlık Kurumları İşletmeciliği programlarında yer alan derslerin üniversitelere göre, zorunlu ve seçmeli ders olma durumlarına göre dağılımı Tablo 1.'de yer almaktadır. Tablo 1. yardımıyla, programların müfredatlarında yer alan toplam ders yükü ve yapısı açısından genel bir profil çıkarmak hedeflenmektedir.

Tablo 1

Türkiye’deki Sağlık Kurumları İşletmeciliği Programlarındaki Ders Sayıları

\begin{tabular}{|c|c|c|c|c|c|}
\hline Üniversite (Devlet/Vakıf) & $\begin{array}{c}\text { Toplam* } \\
\text { Ders } \\
\text { Sayısı }\end{array}$ & $\begin{array}{c}\text { Zorunlu } \\
\text { Ders } \\
\text { Sayısı }\end{array}$ & $\begin{array}{c}\text { Seçmeli } \\
\text { Ders } \\
\text { Sayısı }\end{array}$ & $\begin{array}{c}\text { Zorunlu } \\
\text { Ders } \\
\text { Oranı } \\
\%\end{array}$ & $\begin{array}{c}\text { Seçmeli } \\
\text { Ders } \\
\text { Oranı } \\
\%\end{array}$ \\
\hline Dokuz Eylül Üniversitesi & 43 & 26 & 17 & 60,47 & 39,53 \\
\hline Sağlık Bilimleri Üniversitesi & 33 & 19 & 14 & 57,58 & 42,42 \\
\hline Akdeniz Üniversitesi & 30 & 20 & 10 & 66,67 & 33,33 \\
\hline Nevşehir Hacı Bektaş Veli Üniversitesi & 40 & 25 & 15 & 62,50 & 37,50 \\
\hline Yalova Üniversitesi & 30 & 17 & 13 & 56,67 & 43,33 \\
\hline Uşak Üniversitesi & 50 & 18 & 32 & 36,00 & 64,00 \\
\hline Batman Üniversitesi & 36 & 21 & 15 & 58,33 & 41,67 \\
\hline Balıkesir Üniversitesi & 30 & 20 & 10 & 66,67 & 33,33 \\
\hline Isparta Uygulamalı Bilimler Üniversitesi & 36 & 25 & 11 & 69,44 & 30,56 \\
\hline Kırıkkale Üniversitesi & 30 & 17 & 13 & 56,67 & 43,33 \\
\hline Pamukkale Üniversitesi & 40 & 24 & 16 & 60,00 & 40,00 \\
\hline Karabük Üniversitesi & 43 & 24 & 19 & 55,81 & 44,19 \\
\hline Giresun Üniversitesi & 37 & 22 & 15 & 59,46 & 40,54 \\
\hline Bilecik Şeyh Edebali Üniversitesi & 42 & 18 & 24 & 42,86 & 57,14 \\
\hline Bingöl Üniversitesi & 35 & 15 & 20 & 42,86 & 57,14 \\
\hline Kütahya Dumlupınar Üniversitesi & 34 & 17 & 17 & 50,00 & 50,00 \\
\hline Tokat Gazi Osman Paşa Üniversitesi & 42 & 24 & 18 & 57,14 & 42,86 \\
\hline Kastamonu Üniversitesi & 42 & 24 & 18 & 57,14 & 42,86 \\
\hline Sivas Cumhuriyet Üniversitesi & 39 & 23 & 16 & 58,97 & 41,03 \\
\hline Karamanoğlu Mehmet Bey Üniversitesi & 38 & 26 & 12 & 68,42 & 31,58 \\
\hline Iğdır Üniversitesi & 36 & 19 & 17 & 52,78 & 47,22 \\
\hline Bitlis Eren Üniversitesi & 34 & 17 & 17 & 50,00 & 50,00 \\
\hline Atatürk Üniversitesi & 26 & 18 & 8 & 69,23 & 30,77 \\
\hline Hakkâri Üniversitesi & 39 & 25 & 14 & 64,10 & 35,90 \\
\hline Gümüşhane Üniversitesi & 25 & 18 & 7 & 72,00 & 28,00 \\
\hline Kafkas Üniversitesi & 33 & 23 & 10 & 69,70 & 30,30 \\
\hline Devlet Üniversiteleri / Ortalama & 36 & 21 & 15 & 58,33 & 41,67 \\
\hline Üsküdar Üniversitesi & 24 & 16 & 8 & 66,67 & 30,33 \\
\hline İstanbul Medipol Üniversitesi & 37 & 23 & 14 & 62,16 & 37,84 \\
\hline Ufuk Üniversitesi & 29 & 18 & 11 & 62,07 & 37,93 \\
\hline İstanbul Okan Üniversitesi & 58 & 18 & 40 & 31,03 & 68,97 \\
\hline İstanbul Gelişim Üniversitesi & 50 & 17 & 33 & 34,00 & 66,00 \\
\hline Beykent Üniversitesi & 30 & 16 & 14 & 53,33 & 46,67 \\
\hline İstanbul Kültür Üniversitesi & 70 & 18 & 52 & 25,71 & 74,29 \\
\hline İzmir Kavram Meslek Yüksekokulu & 35 & 16 & 19 & 45,71 & 54,29 \\
\hline Altınbaş Üniversitesi & 32 & 16 & 16 & 50,00 & 50,00 \\
\hline Avrasya Üniversitesi & 30 & 19 & 11 & 63,33 & 36,67 \\
\hline Vakıf Üniversiteleri / Ortalama & 40 & 18 & 22 & 45,00 & 55,00 \\
\hline Genel Ortalama & 37 & 20 & 17 & 53,96 & 46,04 \\
\hline
\end{tabular}


Programların toplam ders sayılarının 24 ile 70 arasında çok geniş bir aralıkta yer almaktadır. En az ders Üsküdar Üniversitesi Sağlık Kurumları İşletmeciliği programında (24) yer alırken en fazla ders ise İstanbul Kültür Üniversitesi'nin Sağlık Kurumları İşletmeciliği programında (70) yer almaktadır. Önlisans düzeyinde eğitim veren birimlerde zorunlu/seçmeli derslerin dağılımı önemli bir noktadır. Bu doğrultuda örnekleme alınan programlarda yer alan derslerin zorunlu ve seçmeli olarak dağılımı incelendiğinde vakıf üniversitelerinin (\%55) kamu üniversitelerine $(\% 41,67)$ göre öğrencilere daha fazla seçmeli ders imkânı sunduğu görülmektedir. Son yıllarda Türkiye'de seçmeli ders sayılarının zorunlu dersler sayısıyla eşit ya da zorunlu derslerden yüksek olması anlayışı hâkimdir. Aynı doğrultuda YÖK üniversitelerde "Bologna Süreci" kapsamında bunu özendirmektedir. 5 devlet üniversitesi ve 5 vakıf üniversitesi olmak üzere 10 üniversitede seçmeli derslerin oranı \%50'nin üzerindedir. Sonuç olarak, üniversitelerin Sağlık Kurumları İşletmeciliği programlarında, zorunlu ders sayısının seçmeli derslerle kıyaslandığında daha yüksek olduğu ve programlar arasında bu konuda önemli farkl11ıklar bulunduğu tespit edilmiştir.

\section{Sağlık Kurumları İşletmeciliği Programlarında Yer Alan Derslerin Çeşitliliğinin Değerlendirilmesi}

Türkiye'de eğitim ve öğretime devam eden Sağlık Kurumları İşletmeciliği programlarının müfredatlarında yer alan dersler incelendiğinde, araştırmaya dâhil edilen üniversitelerde toplam 196 ders bulunduğu tespit edilmiştir. Söz konusu derslerin birçoğunun içeriği ve kapsamı aynı olmasına rağmen isimleri farklıdır. Bu durum Sağlık Kurumları İşletmeciliği programları müfredatlarında bir standardizasyon olmadığını göstermektedir. İlgili derslerin kaç üniversitede $(\mathrm{N})$, hangi dönemde, kaç saat, teorik (T) / uygulama (U), AKTS kredisi ve zorunlu (Z) / seçmeli (S) ders olması durumu ayrıca söz konusu dersler için oluşturulan kategorilere ait veriler Tablo 2.'de yer almaktadır.

Tablo 2

Türkiye'deki Sağlık Kurumları İşletmeciliği Programlarındaki Ders Çeşitliliği $*$ (N=36)

\begin{tabular}{|c|c|c|c|c|c|c|c|c|c|}
\hline Kategori & Dersler & $\mathbf{N}$ & $\%$ & Dönem & $\begin{array}{l}\text { Ders } \\
\text { Saati }\end{array}$ & $\mathbf{T}$ & $\mathbf{U}$ & AKTS & $\mathbf{Z} / \mathbf{S}$ \\
\hline \multirow{20}{*}{ 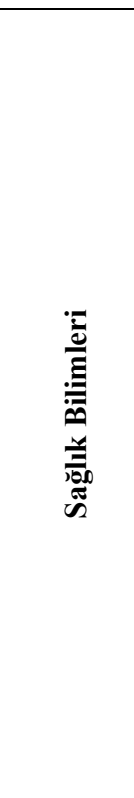 } & Tıbbi Terminolojiye Giriş & 4 & 11 & 1 & $2 / 3$ & $2 / 3$ & 0 & $2 / 3 / 4$ & $\mathrm{Z}$ \\
\hline & Tibbi Terminoloji & 25 & 69 & 1 & 2 & 2 & 0 & $3 / 4$ & $\mathrm{Z}$ \\
\hline & T1bbi Terminoloji 1 & 3 & 8 & 1 & 2 & 2 & 0 & 3 & $\mathrm{Z}$ \\
\hline & T1bbi Terminoloji 2 & 1 & 3 & 2 & 2 & 2 & 0 & 3 & $\mathrm{Z}$ \\
\hline & $\begin{array}{l}\text { Temel Sağlık Bilgisi ve Tibbi } \\
\text { Terminoloji }\end{array}$ & 1 & 3 & 1 & 3 & 3 & 0 & 5 & $\mathrm{~S}$ \\
\hline & Halk Sağlığ & 11 & 31 & $1 / 2 / 3 / 4$ & 2 & 2 & 0 & 3 & $\mathrm{~S}$ \\
\hline & Halk Sağlığı ve Epidemiyoloji & 3 & 8 & 2 & 2 & 2 & 0 & 4 & $\mathrm{Z}$ \\
\hline & Epidemiyoloji & 3 & 8 & $2 / 4$ & 2 & 2 & 0 & 3 & $\mathrm{~S}$ \\
\hline & Radyasyondan Korunma & 1 & 3 & 1 & 2 & 2 & 0 & 2 & $\mathrm{~S}$ \\
\hline & Laboratuvar Teknikleri ve Güvenliği & 2 & 6 & 2 & 2 & 2 & 0 & 2 & $\mathrm{~S}$ \\
\hline & İlk Yardım ve Acil Sağlık Hizmetleri & 2 & 14 & $2 / 4$ & 2 & 2 & 0 & 3 & $\mathrm{~S}$ \\
\hline & İlk Yardım & 21 & 58 & $3 / 4$ & 2 & 2 & 0 & $2 / 3$ & $\mathrm{~S}$ \\
\hline & Acil Yardım & 1 & 3 & 2 & 2 & 2 & 0 & 3 & $\mathrm{~S}$ \\
\hline & Temel Sağlık Bilgisi ve İlk Yardım 1 & 1 & 3 & 3 & 2 & 1 & 1 & 3 & $\mathrm{Z}$ \\
\hline & Temel Sağlık Bilgisi ve İlk Yardım 2 & 1 & 3 & 4 & 2 & 1 & 1 & 3 & $\mathrm{Z}$ \\
\hline & Hastalık Bilgisi & 7 & 19 & 3 & $2 / 3$ & $2 / 3$ & 0 & $3 / 4$ & $\mathrm{~S}$ \\
\hline & Akılcı İlaç Kullanımı & 1 & 3 & 2 & 2 & 2 & 0 & 2 & $\mathrm{~S}$ \\
\hline & Afet ve Acil Durum Yönetimi & 1 & 3 & 3 & 2 & 2 & 0 & 6 & $\mathrm{Z}$ \\
\hline & Temel Afet Bilgisi ve Sivil Savunma & 3 & 8 & 3 & 3 & 3 & 0 & 4 & $\mathrm{~S}$ \\
\hline & Çevre Eğitimi & 1 & 3 & 2 & 2 & 2 & 0 & 3 & $\mathrm{~S}$ \\
\hline \multirow{9}{*}{$\begin{array}{l}\text { 兰 } \\
\text { 站 }\end{array}$} & Hukukun Temel Kavramları & 33 & 92 & 1 & 2 & 2 & 0 & 3 & $\mathrm{Z}$ \\
\hline & İdare Hukuku & 4 & 11 & 2 & 2 & 2 & 0 & 3 & $\mathrm{Z}$ \\
\hline & Ticaret Hukuku & 1 & 3 & 2 & 3 & 3 & 0 & 5 & $\mathrm{Z}$ \\
\hline & Borçlar Hukuku & 1 & 3 & 3 & 2 & 2 & 0 & 3 & $\mathrm{~S}$ \\
\hline & İş ve Sosyal Güvenlik Hukuku & 21 & 58 & 4 & 2 & 2 & 0 & 3 & $\mathrm{~S}$ \\
\hline & $\begin{array}{l}\text { Sağlık Kurumlarında İş Sağlığı ve } \\
\text { Güvenliği }\end{array}$ & 26 & 72 & 2 & 2 & 2 & 0 & 3 & $\mathrm{~S}$ \\
\hline & Hasta ve Çalışan Güvenliği & 1 & 3 & 2 & 3 & 3 & 0 & 5 & $\mathrm{Z}$ \\
\hline & Sağlık Yönetiminde Etik & 3 & 8 & $2 / 3$ & 2 & 2 & 0 & 2 & $\mathrm{~S}$ \\
\hline & Sosyal Sorumluluk ve Etik & 1 & 3 & 3 & 2 & 2 & 0 & 2 & $\mathrm{~S}$ \\
\hline
\end{tabular}




\begin{tabular}{|c|c|c|c|c|c|c|c|c|c|}
\hline & T1bbi Etik ve Hasta Hakları & 2 & 6 & 3 & 2 & 2 & 0 & 2 & $\mathrm{~S}$ \\
\hline & Meslek Etiği & 19 & 53 & 4 & 2 & 2 & 0 & 3 & $\mathrm{~S}$ \\
\hline & Sağl1k Yönetimi Etiği & 1 & 3 & 2 & 3 & 3 & 0 & 3 & $\mathrm{~S}$ \\
\hline & İş Ahlakı & 1 & 3 & 2 & 2 & 2 & 0 & 2 & $\mathrm{~S}$ \\
\hline & Sağlık Mevzuatı & 12 & 33 & $3 / 4$ & 2 & 2 & 0 & $3 / 4$ & $\mathrm{Z}$ \\
\hline & Sağlık Kurumları Mevzuatı & 5 & 14 & $3 / 4$ & $2 / 3$ & $2 / 3$ & 0 & $3 / 4$ & $\mathrm{Z}$ \\
\hline & Sağlık Hukuku ve Mevzuatı & 3 & 8 & $3 / 4$ & $2 / 3$ & $2 / 3$ & 0 & 4 & $\mathrm{Z}$ \\
\hline & Sağlık Hukuku & 11 & 31 & $2 / 3 / 4$ & $2 / 3$ & $2 / 3$ & 0 & 3 & $\mathrm{Z}$ \\
\hline & Hasta Hakları & 12 & 33 & $3 / 4$ & $2 / 3$ & $2 / 3$ & 0 & 3 & $\mathrm{~S}$ \\
\hline \multirow{3}{*}{ 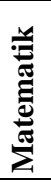 } & Matematik & 10 & 28 & 1 & 3 & 3 & 0 & 3 & $\mathrm{Z}$ \\
\hline & Genel Matematik & 5 & 14 & 1 & 2 & 2 & 0 & 4 & $\mathrm{~S}$ \\
\hline & Ticari Matematik & 6 & 17 & 1 & 2 & 2 & 0 & 3 & $\mathrm{~S}$ \\
\hline \multirow{27}{*}{ 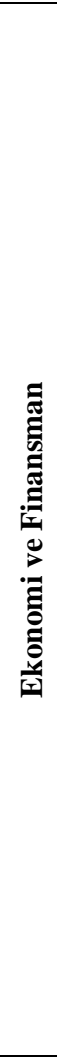 } & Genel Muhasebe & 25 & 69 & 1 & 3 & 3 & 0 & 4 & $\mathrm{Z}$ \\
\hline & Genel Muhasebe 1 & 10 & 28 & 1 & 3 & 3 & 0 & 4 & $\mathrm{Z}$ \\
\hline & Genel Muhasebe 2 & 10 & 28 & 2 & 3 & 3 & 0 & 4 & $\mathrm{Z}$ \\
\hline & Dönem Sonu Muhasebe İşlemleri & 6 & 17 & 2 & 3 & 3 & 0 & 4 & $\mathrm{Z}$ \\
\hline & Genel İktisat ve Muhasebe Uygulamaları & 1 & 3 & 2 & 3 & 3 & 0 & 10 & $\mathrm{Z}$ \\
\hline & Medikal Muhasebe & 1 & 3 & 2 & 3 & 3 & 0 & 4 & $\mathrm{Z}$ \\
\hline & Maliyet Muhasebesi & 26 & 72 & $3 / 4$ & 3 & 3 & 0 & $4 / 5$ & $\mathrm{Z}$ \\
\hline & Yönetim Muhasebesi & 2 & 6 & 3 & 3 & 3 & 0 & 3 & $\mathrm{~S}$ \\
\hline & Hastanelerde Mali Yönetim & 3 & 8 & $3 / 4$ & 2 & 2 & 0 & 2 & $\mathrm{~S}$ \\
\hline & Sağlık Kurumlarında Maliyet Yönetimi & 1 & 3 & 4 & 3 & 3 & 0 & 4 & $\mathrm{Z}$ \\
\hline & Sağllk Sigortacılı̆̆ 1 & 26 & 72 & 3 & 2 & 2 & 0 & 3 & $\mathrm{~S}$ \\
\hline & Finansal Yönetim & 29 & 81 & $3 / 4$ & 3 & 3 & 0 & 4 & $\mathrm{Z}$ \\
\hline & Finansal Okur Yazarlık & 2 & 6 & $3 / 4$ & 2 & 2 & 0 & 3 & $\mathrm{~S}$ \\
\hline & Finansal Kurumlar & 1 & 3 & 3 & 3 & 3 & 0 & 5 & $\mathrm{~S}$ \\
\hline & Sağlık Ekonomisi & 16 & 44 & 3 & 2 & 2 & 0 & 4 & $\mathrm{Z}$ \\
\hline & Mikro Ekonomi & 3 & 8 & 1 & 3 & 3 & 0 & 3 & $\mathrm{Z}$ \\
\hline & Makro Ekonomi & 3 & 8 & 2 & 3 & 3 & 0 & 3 & $\mathrm{Z}$ \\
\hline & Genel Ekonomi & 12 & 33 & 1 & 3 & 3 & 0 & 3 & $\mathrm{Z}$ \\
\hline & İktisada Giriş & 9 & 25 & 1 & 3 & 3 & 0 & 3 & $\mathrm{Z}$ \\
\hline & $\begin{array}{l}\text { Sağlık Kurumlarında Lojistik ve Satın } \\
\text { Alma }\end{array}$ & 2 & 6 & 3 & 3 & 3 & 0 & 4 & S \\
\hline & Bilgisayarlı Muhasebe & 4 & 11 & $2 / 3 / 4$ & 3 & 1 & 2 & 3 & $\mathrm{~S}$ \\
\hline & Satın alma ve Tedarik Yönetimi & 6 & 17 & 4 & 2 & 2 & 0 & 3 & $\mathrm{~S}$ \\
\hline & Tedarik Zinciri ve Malzeme Yönetimi & 3 & 8 & 3 & 2 & 2 & 0 & 3 & $\mathrm{~S}$ \\
\hline & Sağl1k Hizmetlerinde Lojistik Yönetimi & 7 & 19 & 4 & 2 & 2 & 0 & 4 & $\mathrm{~S}$ \\
\hline & Sağl1k Kurumlarında Kaynak Yönetimi & 4 & 11 & 4 & 2 & 2 & 0 & 3 & $\mathrm{~S}$ \\
\hline & Sağlık Kurumlarında Kaynak Planlaması & 7 & 19 & $3 / 4$ & 2 & 2 & 0 & 4 & $\mathrm{Z}$ \\
\hline & Sağlık Kurumlarında Üretim Yönetimi & 7 & 19 & 3 & 2 & 2 & 0 & 3 & $\mathrm{~S}$ \\
\hline \multirow{6}{*}{$\begin{array}{l}:=\overline{0} \\
\frac{0}{0} \\
\stackrel{0}{0} \\
\stackrel{0}{0}\end{array}$} & Sağl1k Sosyolojisi & 10 & 28 & 4 & 2 & 2 & 0 & 3 & $\mathrm{~S}$ \\
\hline & Sosyoloji & 1 & 3 & 4 & 2 & 2 & 0 & 4 & $\mathrm{~S}$ \\
\hline & Sağllk ve Toplum & 2 & 6 & 4 & 2 & 2 & 0 & 2 & $\mathrm{~S}$ \\
\hline & Toplumsal Cinsiyet Eşitliği & 1 & 3 & 2 & 2 & 2 & 0 & 2 & $\mathrm{~S}$ \\
\hline & Kadın ve Aile Hayatı & 1 & 3 & 2 & 2 & 2 & 0 & 2 & $\mathrm{~S}$ \\
\hline & Engellilik ve Yaşam & 1 & 3 & 2 & 2 & 2 & 0 & 2 & $\mathrm{~S}$ \\
\hline \multirow{14}{*}{ 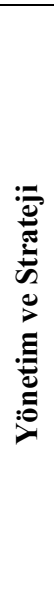 } & Sağlık Kurumları Yönetimi 1 & 22 & 61 & $2 / 3$ & 3 & 3 & 0 & 4 & $\mathrm{Z}$ \\
\hline & Sağlık Kurumları İşletmeciliği 1 & 2 & 6 & 3 & $2 / 3$ & $2 / 3$ & 0 & 4 & $\mathrm{Z}$ \\
\hline & Sağlık Hizmetleri Yönetimi & 5 & 14 & 2 & $2 / 3$ & $2 / 3$ & 0 & 4 & $\mathrm{Z}$ \\
\hline & Sağlık Politikaları ve Planlaması & 9 & 25 & $3 / 4$ & 2 & 2 & 0 & $3 / 4$ & $\mathrm{Z}$ \\
\hline & $\begin{array}{l}\text { Sağlık Hizmetlerinde Planlama } \\
\text { Teknikleri }\end{array}$ & 1 & 3 & 3 & 2 & 2 & 0 & 3 & $\mathrm{Z}$ \\
\hline & Sağlık politikası & 3 & 8 & 4 & 3 & 3 & 0 & 4 & $\mathrm{~S}$ \\
\hline & Sağlık Planlaması & 1 & 3 & 4 & 3 & 3 & 0 & 3 & $\mathrm{~S}$ \\
\hline & Kriz ve Afet Yönetimi & 4 & 11 & 4 & 2 & 2 & 0 & $2 / 4$ & $\mathrm{~S}$ \\
\hline & Risk Yönetimi & 3 & 8 & 3 & 2 & 2 & 0 & 4 & $\mathrm{~S}$ \\
\hline & İnsan Kaynakları Yönetimi & 33 & 92 & $3 / 4$ & 3 & 3 & 0 & 3 & $\mathrm{Z}$ \\
\hline & Liderlik & 1 & 3 & 3 & 2 & 2 & 0 & 3 & $\mathrm{~S}$ \\
\hline & Liderlik ve Zaman Yönetimi & 2 & 6 & 3 & 2 & 2 & 0 & 4 & $\mathrm{~S}$ \\
\hline & Kriz ve Stres Yönetimi & 7 & 19 & $3 / 4$ & 2 & 2 & 0 & $2 / 3$ & $\mathrm{~S}$ \\
\hline & $\begin{array}{l}\text { Sağlık Kurumlarında Operasyon } \\
\text { Yönetimi }\end{array}$ & 2 & 6 & 3 & 3 & 3 & 0 & 5 & $\mathrm{~S}$ \\
\hline
\end{tabular}




\begin{tabular}{|c|c|c|c|c|c|c|c|c|c|}
\hline & Stratejik Yönetim & 10 & 28 & $3 / 4$ & 2 & 2 & 0 & 3 & $\mathrm{~S}$ \\
\hline & Hastane Yönetim ve Organizasyonu 2 & 6 & 17 & 2 & 3 & 3 & 0 & 4 & $\mathrm{Z}$ \\
\hline & Hastane İdaresi & 1 & 3 & 2 & 2 & 2 & 0 & 3 & $\mathrm{Z}$ \\
\hline & Hastane Yönetim ve Organizasyonu 3 & 1 & 3 & 3 & 4 & 4 & 0 & 4 & $\mathrm{Z}$ \\
\hline & Hastane Yönetim ve Organizasyonu 4 & 1 & 3 & 4 & 4 & 4 & 0 & 4 & $\mathrm{Z}$ \\
\hline & Hastane Anatomisi & 1 & 3 & 1 & 3 & 3 & 0 & 5 & $\mathrm{Z}$ \\
\hline & Hastane Yönetim ve Organizasyonu 1 & 8 & 22 & 3 & $2 / 3$ & $2 / 3$ & 0 & 4 & $\mathrm{Z}$ \\
\hline & Sağlık Kurumları İşletmeciliği 2 & 2 & 6 & $2 / 4$ & 2 & 2 & 0 & 4 & $\mathrm{Z}$ \\
\hline & Sağlık Kurumları Yönetimi 2 & 8 & 22 & $2 / 4$ & 3 & 3 & 0 & 5 & $\mathrm{Z}$ \\
\hline & Sağlık Kurumlarında Denetim & 1 & 3 & 3 & 2 & 2 & 0 & 3 & $\mathrm{~S}$ \\
\hline & Hasta Hizmetleri Yönetimi & 2 & 6 & $1 / 2$ & $2 / 3$ & $2 / 3$ & 0 & $2 / 7$ & $\mathrm{Z} / \mathrm{S}$ \\
\hline & Hastane Yönetim ve Organizasyonu 2 & 6 & 17 & 2 & 3 & 3 & 0 & 4 & Z \\
\hline & Yönetim ve Organizasyon & 15 & 42 & $1 / 2$ & 3 & 3 & 0 & 4 & $\mathrm{Z}$ \\
\hline & Yönetim Teorileri & 2 & 6 & 2 & 2 & 2 & 0 & 3 & $\mathrm{~S}$ \\
\hline & Yönetimde Güncel Yaklaşımları & 2 & 6 & 2 & 2 & 2 & 0 & 2 & $\mathrm{~S}$ \\
\hline & Zaman ve Toplantı Yönetimi & 3 & 8 & 1 & 2 & 2 & 0 & 4 & $\mathrm{~S}$ \\
\hline & Karşılaştırmalı Sağlık Sistemleri & 13 & 36 & 4 & 2 & 2 & 0 & $3 / 4$ & $\mathrm{~S}$ \\
\hline & Türk Sağlık Sistemi & 3 & 8 & 4 & 2 & 2 & 0 & 3 & $\mathrm{~S}$ \\
\hline & Sağlık Turizmi & 13 & 36 & 3 & 2 & 2 & 0 & 3 & $\mathrm{~S}$ \\
\hline & Örgütsel Davranış & 13 & 36 & $3 / 4$ & 2 & 2 & 0 & $3 / 4$ & $\mathrm{~S}$ \\
\hline \multirow{11}{*}{ 荡 } & Halkla İlişkiler & 22 & 61 & $2 / 3 / 4$ & 2 & 2 & 0 & 3 & $\mathrm{~S}$ \\
\hline & Halkla İlişkiler ve İletişim & 6 & 17 & $1 / 2$ & 3 & 3 & 0 & 3 & $\mathrm{~S}$ \\
\hline & İletişim & 20 & 56 & $1 / 2 / 3 / 4$ & 2 & 2 & 0 & $2 / 3$ & $\mathrm{~S}$ \\
\hline & Sağlık İletişimi & 3 & 8 & $3 / 4$ & 3 & 3 & 0 & $2 / 4 / 5$ & $\mathrm{~S}$ \\
\hline & Kurumsal İletişim & 2 & 6 & 4 & 3 & 3 & 0 & 4 & $\mathrm{~S}$ \\
\hline & Protokol Bilgisi & 1 & 3 & 2 & 2 & 2 & 0 & 3 & $\mathrm{~S}$ \\
\hline & Kişiler arası İlişkiler & 3 & 8 & $3 / 4$ & 3 & 3 & 0 & 4 & $\mathrm{~S}$ \\
\hline & Güzel Konuşma ve Diksiyon & 5 & 14 & 4 & 2 & 2 & 0 & $2 / 3$ & $\mathrm{~S}$ \\
\hline & Medya Okur Yazarlığ 1 & 1 & 3 & 4 & 2 & 2 & 0 & 2 & $\mathrm{~S}$ \\
\hline & Etkili Konuşma ve Yazışma & 3 & 8 & 3 & 2 & 2 & 0 & 3 & $\mathrm{~S}$ \\
\hline & İşaret Dili & 6 & 17 & 2 & 2 & 2 & 0 & 2 & $\mathrm{~S}$ \\
\hline \multirow{16}{*}{ 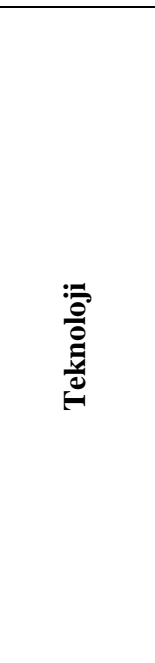 } & Sağlık Kurumlarında Otomasyon 1 & 13 & 36 & 2 & 4 & 2 & 2 & 4 & $\mathrm{Z}$ \\
\hline & Sağlık Kurumlarında Otomasyon 2 & 1 & 3 & 4 & 3 & 3 & 0 & 3 & $\mathrm{Z}$ \\
\hline & $\begin{array}{l}\text { Sağlik Kurumlarında Yönetim Bilgi } \\
\text { Sistemleri }\end{array}$ & 20 & 56 & $3 / 4$ & 3 & 2 & 1 & 3 & $\mathrm{Z}$ \\
\hline & Hastanelerde Bilgi İşlem & 3 & 6 & $2 / 4$ & 3 & 3 & 0 & 4 & $\mathrm{~S}$ \\
\hline & Yönetim Bilişim Sistemleri & 2 & 6 & $3 / 4$ & 2 & 2 & 0 & 5 & $\mathrm{Z}$ \\
\hline & Bilgi Yönetimi & 1 & 3 & 4 & 3 & 3 & 0 & 3 & $\mathrm{Z}$ \\
\hline & Sağlık Kayıt Sistemleri & 1 & 3 & 3 & 2 & 2 & 0 & 2 & $\mathrm{~S}$ \\
\hline & Bilgi İletişim Teknolojisi & 6 & 17 & $2 / 3 / 4$ & 3 & 2 & 1 & 3 & $\mathrm{Z}$ \\
\hline & T1bbi Cihaz Teknolojisi & 1 & 3 & 3 & 2 & 2 & 0 & 2 & $\mathrm{~S}$ \\
\hline & Bilgisayar 1 & 8 & 22 & 1 & 2 & 2 & 0 & 3 & $\mathrm{Z}$ \\
\hline & Bilgisayar Uygulamaları & 3 & 8 & 1 & 3 & 2 & 1 & 3 & $\mathrm{Z}$ \\
\hline & Temel Bilgi Teknolojisi Kullanımı 1 & 12 & 33 & 1 & 3 & 2 & 1 & 4 & $\mathrm{Z}$ \\
\hline & Bilgisayar 2 & 2 & 6 & 2 & 3 & 2 & 1 & 3 & $\mathrm{~S}$ \\
\hline & Temel Bilgi Teknolojisi Kullanımı 2 & 4 & 11 & 2 & 4 & 2 & 2 & 3 & $\mathrm{Z}$ \\
\hline & Ofis Yazılımları & 4 & 11 & 1 & 3 & 2 & 1 & 4 & $\mathrm{~S}$ \\
\hline & Klavye Teknikleri & 1 & 3 & 2 & 4 & 3 & 1 & 5 & $\mathrm{~S}$ \\
\hline \multirow{10}{*}{ 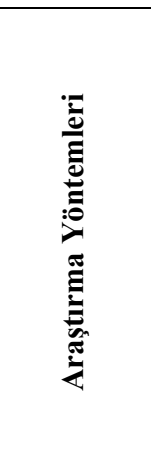 } & İstatistik & 9 & 25 & 2 & 2 & 2 & 0 & 3 & $\mathrm{Z}$ \\
\hline & Sağlık Yönetiminde İstatistik & 2 & 6 & $2 / 4$ & 2 & 2 & 0 & 3 & $\mathrm{Z}$ \\
\hline & Biyoistatistik & 20 & 56 & $2 / 3$ & 3 & 3 & 0 & $3 / 4$ & $\mathrm{Z}$ \\
\hline & $\begin{array}{l}\text { Sağlık Yönetiminde Araştırma } \\
\text { Yöntemleri }\end{array}$ & 18 & 50 & 4 & 2 & 2 & 0 & 3 & S \\
\hline & Nitel Araştırma Yöntemleri & 1 & 3 & 3 & 2 & 2 & 0 & 2 & $\mathrm{~S}$ \\
\hline & $\begin{array}{l}\text { Sağlık İşletmelerinde Kantitatif } \\
\text { Teknikler }\end{array}$ & 1 & 3 & 4 & 3 & 3 & 0 & 5 & $\mathrm{~S}$ \\
\hline & Sağlık Yönetiminde Seminer & 2 & 6 & 4 & $1 / 3$ & $1 / 3$ & 0 & $2 / 4$ & $\mathrm{~S}$ \\
\hline & Bitirme Projesi & 4 & 11 & 4 & 2 & 0 & 2 & 4 & $\mathrm{~S}$ \\
\hline & Eleştirel Düşünme & 1 & 3 & 4 & 2 & 2 & 0 & 2 & $\mathrm{~S}$ \\
\hline & Proje Yönetimi & 2 & 6 & 3 & 4 & 2 & 2 & 4 & $\mathrm{~S}$ \\
\hline \multirow{3}{*}{ 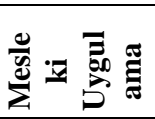 } & Sağlık Kurumlarında Alan Çalışması 1 & 9 & 25 & 3 & $6 / 8$ & 0 & $6 / 8$ & 8 & $\mathrm{Z}$ \\
\hline & Mesleki Çalışma 1 & 1 & 3 & 3 & 4 & 2 & 2 & 5 & $\mathrm{Z}$ \\
\hline & Yönlendirilmiş Çalışma 1 & 3 & 8 & 3 & 2 & 0 & 2 & 4 & $\mathrm{~S}$ \\
\hline
\end{tabular}




\begin{tabular}{|c|c|c|c|c|c|c|c|c|c|}
\hline & Sağlık Kurumlarında Alan Çalışması 2 & 6 & 17 & 4 & 8 & 0 & 8 & $4 / 6$ & $\mathrm{Z}$ \\
\hline & Mesleki Çalışma 2 & 1 & 3 & 4 & 4 & 2 & 2 & 5 & $\mathrm{Z}$ \\
\hline & Yönlendirilmiş Çalışma 2 & 1 & 3 & 4 & 2 & 0 & 2 & 2 & $\mathrm{~S}$ \\
\hline & İşyeri Eğitimi & 1 & 3 & 4 & 4 & 4 & 0 & 4 & $\mathrm{Z}$ \\
\hline & İşyeri Eğitimi Uygulamaları & 4 & 11 & 4 & 8 & 0 & 8 & 6 & $\mathrm{Z}$ \\
\hline & Staj & 17 & 47 & 4 & 0 & 0 & 0 & $4 / 8 / 10$ & $\mathrm{Z}$ \\
\hline & Yaz Staj1 & 13 & 36 & 4 & 0 & 0 & 0 & $4 / 8$ & $\mathrm{Z}$ \\
\hline & Bilimsel ve Kültürel Etkinlikler & 1 & 3 & 1 & 2 & 2 & 0 & 3 & $\mathrm{~S}$ \\
\hline & Sağlık Hizmetlerinde Sosyal Sorumluluk & 1 & 3 & 3 & 2 & 2 & 0 & 3 & $\mathrm{~S}$ \\
\hline & İş Yaşamına Hazırlık & 1 & 3 & 4 & 2 & 2 & 0 & 2 & $\mathrm{~S}$ \\
\hline & İş Arama Teknikleri & 1 & 3 & 4 & 2 & 2 & 0 & 2 & $\mathrm{~S}$ \\
\hline & Kariyer Planlama & 3 & 8 & 3 & 2 & 2 & 0 & 2 & $\mathrm{~S}$ \\
\hline \multirow{10}{*}{ 馬 } & Yaratıcı Drama & 1 & 3 & 1 & 2 & 2 & 0 & 3 & $\mathrm{~S}$ \\
\hline & Fotoğrafçılık & 1 & 3 & 4 & 2 & 2 & 0 & 3 & $\mathrm{~S}$ \\
\hline & Görsel Sanatlar & 1 & 3 & 1 & 2 & 2 & 0 & 2 & $\mathrm{~S}$ \\
\hline & Güzel Sanatlar & 1 & 3 & 1 & 2 & 2 & 0 & 2 & $\mathrm{~S}$ \\
\hline & Tip Fotoğrafçı1lı̆̆1 & 1 & 3 & 2 & 3 & 3 & 0 & 4 & $\mathrm{~S}$ \\
\hline & Tip Ressamlığ & 1 & 3 & 2 & 3 & 3 & 0 & 4 & $\mathrm{~S}$ \\
\hline & Sağlık ve Tiyatro & 1 & 3 & 2 & 3 & 3 & 0 & 4 & $\mathrm{~S}$ \\
\hline & Sağlık ve Sanat & 1 & 3 & 2 & 3 & 3 & 0 & 4 & $\mathrm{~S}$ \\
\hline & Sağlık ve Mimarlık & 1 & 3 & 2 & 3 & 3 & 0 & 4 & $\mathrm{~S}$ \\
\hline & Sağlık ve Sinema & 1 & 3 & 2 & 3 & 3 & 0 & 4 & $\mathrm{~S}$ \\
\hline \multirow{3}{*}{ 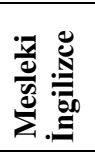 } & Mesleki İngilizce & 16 & 44 & $3 / 4$ & 2 & 2 & 0 & $3 / 4$ & $\mathrm{~S}$ \\
\hline & T1bbi İngilizce 1 & 1 & 3 & 4 & 3 & 3 & 0 & 4 & S \\
\hline & Trbbi İngilizce 2 & 1 & 3 & 4 & 3 & 3 & 0 & 4 & $\mathrm{~S}$ \\
\hline \multirow{2}{*}{ 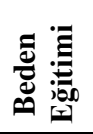 } & Beden Eğitimi & 4 & 11 & 2 & 2 & 2 & 0 & 2 & $\mathrm{~S}$ \\
\hline & Aikido & 1 & 3 & 1 & 2 & 1 & 1 & 2 & $\mathrm{~S}$ \\
\hline \multirow{5}{*}{$\begin{array}{l}:=\frac{0}{0} \\
\frac{0}{0} \\
\frac{1}{0} \\
0\end{array}$} & Sağlık Psikolojisi & 11 & 31 & $3 / 4$ & 2 & 2 & 0 & 3 & $\mathrm{~S}$ \\
\hline & Psikoloji & 2 & 6 & 2 & 2 & 2 & 0 & 2 & $\mathrm{~S}$ \\
\hline & Sosyal Hizmetler & 1 & 3 & 4 & 3 & 3 & 0 & 4 & $\mathrm{~S}$ \\
\hline & Psikolojik Danışmanlık ve Rehberlik & 1 & 3 & 3 & 3 & 3 & 0 & 3 & $\mathrm{~S}$ \\
\hline & Davranış Bilimleri & 22 & 61 & 2 & 2 & 2 & 0 & 3 & $\mathrm{~S}$ \\
\hline \multirow{4}{*}{ 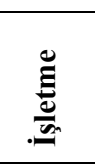 } & Genel İşletme & 31 & 86 & 1 & 3 & 3 & 0 & $3 / 4 / 5$ & $\mathrm{Z}$ \\
\hline & İşletme Yönetimi 1 & 4 & 11 & 1 & 3 & 3 & 0 & 4 & $\mathrm{Z}$ \\
\hline & İşletme Yönetimi 2 & 3 & 8 & 2 & 3 & 3 & 0 & 4 & $\mathrm{Z}$ \\
\hline & Girişimcilik & 25 & 69 & 3 & 2 & 2 & 0 & 4 & $\mathrm{~S}$ \\
\hline \multirow{5}{*}{ 胥 } & Sağlık Kurumlarında Pazarlama & 35 & 97 & $3 / 4$ & 3 & 3 & 0 & $3 / 4$ & $\mathrm{Z}$ \\
\hline & $\begin{array}{l}\text { Sağlık Kurumlarında Halkla İlişsiler ve } \\
\text { Pazarlama }\end{array}$ & 4 & 11 & $3 / 4$ & 3 & 3 & 0 & $5 / 6$ & $\mathrm{~S}$ \\
\hline & Sağlıkta Tüketici Davranışları & 3 & 8 & $3 / 4$ & 2 & 2 & 0 & 3 & $\mathrm{~S}$ \\
\hline & Marka Yönetimi & 3 & 8 & 3 & 3 & 3 & 0 & 3 & $\mathrm{~S}$ \\
\hline & Müşteri İlişkileri Yönetimi & 9 & 25 & 3 & 3 & 3 & 0 & 4 & $\mathrm{~S}$ \\
\hline \multirow{4}{*}{ 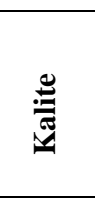 } & Sağlık Kurumlarında Kalite Yönetimi & 22 & 61 & 4 & $2 / 3$ & $2 / 3$ & 0 & $3 / 4$ & $\mathrm{Z}$ \\
\hline & Toplam Kalite Yönetimi & 9 & 25 & 3 & $2 / 3$ & $2 / 3$ & 0 & $3 / 4$ & $\mathrm{~S}$ \\
\hline & $\begin{array}{l}\text { Sağlık Kurumlarında Kalite ve } \\
\text { Akreditasyon }\end{array}$ & 4 & 11 & 4 & $2 / 3$ & $2 / 3$ & 0 & 4 & $\mathrm{Z}$ \\
\hline & Kalite Yönetim Sistemleri ve Standartları & 2 & 6 & 4 & $2 / 3$ & $2 / 3$ & 0 & 4 & $\mathrm{~S}$ \\
\hline \multirow{3}{*}{ 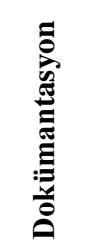 } & T1bbi Dokümantasyon ve Arşivleme & 29 & 81 & 3 & 2 & 2 & 0 & 4 & $\mathrm{Z}$ \\
\hline & T1p Kütüphaneciliği & 1 & 3 & 1 & 2 & 2 & 0 & 3 & S \\
\hline & Yazışma ve Raporlama Teknikleri & 19 & 53 & $2 / 3 / 4$ & 2 & 2 & 0 & 3 & $\mathrm{~S}$ \\
\hline
\end{tabular}

“/” işaretiyle ayrılmış veriler üniversitelerde farklılık gösteren değerleri ifade etmektedir.

Araştırma kapsamında Sağlık Kurumları İşletmeciliği önlisans programlarında yer alan 196 ders tespit edilmiştir. Söz konusu dersler, kapsamları ve içerikleri açısında kategorilere ayrılmıştır. Bu kapsamda dersler; "sağllk bilimleri, hukuk matematik, ekonomi ve finansman, sosyoloji, yönetim ve strateji, iletişim, teknoloji, araştırma yöntemleri, mesleki uygulama, sanat, mesleki İngilizce, beden 
eğitimi, psikoloji, işletme, pazarlama, kalite, dokümantasyon” olmak üzere 18 kategoride bir araya getirilmiştir. Başta sağlık, yönetim, ekonomi ve hukuk alanlarında olmak üzere verilen derslerin dağılımı, Türkiye'de Sağlık Kurumları İşletmeciliği önlisans programlarında 18 farklı alanda ders alarak yetiştirildiğini göstermekte ve mezun olacak öğrencilerin aldıkları dersler açısından yetkinlikleri konusunda fikir vermektedir. Ayrıca tablo 2. Sağlı Kurumları İşletmeciliği programlarında yer alan derslerin, isimlerinin, teorik ya da uygulama olarak saatlerinin, zorunlu ya da seçmeli olma durumlarının, AKTS bilgilerinin ve hangi dönemde yer aldıklarının gösterildiği bir rehber hüviyetindedir. Bu özelliğiyle Tablo 2.'nin müfredat geliştirme ve değiştirme çalışmalarında örnek teşkil edecek bir kaynak olacağı düşünülmektedir.

\section{Sonuç, Tartışma ve Öneriler}

$\mathrm{Bu}$ araştırmada, Türkiye'de 36 üniversitenin önlisans düzeyinde eğitim vermekte olan Sağlik Kurumları İşletmeciliği programlarının ders çeşitliliği incelenmiştir. Programların toplam ders sayılarının 24 ile 70 arasında çok geniş bir aralıkta yer almaktadır. En az ders Üsküdar Üniversitesi Sağlık Kurumları İşletmeciliği programında (24) yer alırken en fazla ders ise İstanbul Kültür Üniversitesi'nin Sağlık Kurumları İşletmeciliği Programında (70) yer almaktadır. Devlet üniversitelerinde ortalama 36 ders bulunurken vakıf üniversitelerinde ortalama 40 ders vardır. Derslerin zorunlu ve seçmeli olmasına göre dağılımlarında devlet ve vakıf üniversitelerinde farklılıklar bulunmaktadır. Kamu üniversitelerinde daha çok zorunlu dersler bulunurken vakıf üniversitelerinde daha çok seçmeli dersler bulunmaktadır. Vakıf üniversitelerinin (\%55) kamu üniversitelerine $(\% 41,67)$ göre öğrencilere daha fazla seçmeli ders imkânı sunduğu görülmektedir. Türkiye'de üniversitelerin Bologna sürecinin benimsemesi ile birlikte YÖK'ün tavsiye kararları zorunlu ve seçmeli ders dağılımının eşit veya seçmeli derslerin daha fazla olması yönündedir (Yılmaz, 2018, s. 50). 5 devlet, 5 vakıf üniversitesi olmak üzere 10 üniversitede seçmeli ders oran $1 \% 50$ ve üstündedir. Sonuç olarak, üniversitelerin Sağlık Kurumları İşletmeciliği programlarında, zorunlu ders sayısının seçmeli derslerle kıyaslandığında daha yüksek olduğu ve programlar arasında bu konuda önemli farklılıklar bulunduğu tespit edilmiştir.

Bazı üniversitelerde seçmeli ders sayısının çok olmasına rağmen fiziki imkânların yetersizliği nedeniyle öğrencilerin seçmeli ders havuzunda yer alan bazı dersleri seçemedikleri bilinmektedir. Bu durumda öğrenciler için seçmeli derslerin zorunlu derslerden bir farkı kalmamaktadır. Pandemi sürecinde daha yakından tecrübe edilen uzaktan eğitim ile fiziki imkânlarla ilgili sıkıntılar giderilebilmektedir. Dolayısıyla uygun olan seçmeli derslerin, YÖK'ün açılan derslerin \%40'ına kadar uzaktan eğitimle verilmesi önerisi doğrultusunda uzaktan eğitim yöntemi kullanılarak verilmesi önerilmektedir. Bu yöntemle fiziksel imkânsızlıklar nedeniyle açılamayan seçmeli derslerin açılmasına olanak sağlanabilir. Böylece öğrencilere seçmeli derslerle ilgili tercih hakkı sağlanmış olacaktır.

Araştırma kapsamında Sağlık Kurumları İşletmeciliği önlisans programlarında yer alan 196 ders; "sağlik bilimleri, hukuk matematik, ekonomi ve finansman, sosyoloji, yönetim ve strateji, iletişim, teknoloji, araştırma yöntemleri, mesleki uygulama, sanat, mesleki İngilizce, beden eğitimi, psikoloji, işletme, pazarlama, kalite, dokümantasyon" olmak üzere 18 kategoride bir araya getirilmiştir. Sağlık Kurumları İşletmeciliği programı mezunu öğrencilerin başta hastaneler olmak üzere, aile sağlığı merkezleri, eczaneler, medikal işletmelerinde idari personel olarak görev yapmaları beklenmektedir. Bu bağlamda öğrenciler temel sağlık bilgileri, tıbbi dokümantasyon, hastane bilişim sistemleri ve tıbbi terminolojinin yanı sıra yönetim, temel işletme bilgileri, muhasebe, finansman, pazarlama, halkla ilişkiler, insan kaynakları, sosyoloji, psikoloji alanlarında dersler almaktadır. Multidisipliner bir alan olan sağlık hizmetlerinin sunumuna yönelik bilgilerle öğrencilerin sağllk sektöründe idari personel olmalarına yönelik yetiştirildiği görülmektedir. Sağlık Kurumları İşletmeciliği programı mezunu öğrencilerin sağlı kuruluşlarında sağlık personelinin hizmet sunumuna destek olmak üzer idari personel olarak görevlendirilmeleri ayrıca gerek kamu gerekse özel sağlık kuruluşlarında insan kaynakları planlamasında Sağlık Kurumları İşletmeciliği mezunlarının da değerlendirilmesi önerilmektedir. 
Sağlık Kurumları İşletmeciliği programı müfredatları incelendiğinde ders sayılarının ve çeşitliliğinin çok olduğu görülmektedir. Ders çeşitliliğinin fazla gözükmekle birlikte benzer içerikteki dersler farklı isimlerle müfredata konulduğu görülmektedir. Bu durum karışıklık yaratmaktadır. Alanın uzmanları tarafından yapılacak çalıştaylarla benzer içerikli derslerin isimlendirilmelerinde standartın sağlanması gereklidir. Ayrıca üniversitelerin özerk yapısı da dikkate alınarak ders içerikleri, ders sayıları ve ders isimlendirmeleri anlamında tavsiye kararlar alınmalıdır.

Meslek Yüksekokullarının en önemli görevlerinden birisi de hitap ettiği sektörün ihtiyaç duyduğu nitelikli personeli yetiştirmektir. Müfredatta güncelleme çalışmalarında üniversite eğitimi ile sektörün beklentilerinin uyumlulaştırılması anlamında sağlık sektörü temsilcilerinden görüş alınmalıdır. Bu bağlamda Yükseköğretim Kalite Kurulu'nun (YÖKAK) da önerisi doğrultusunda program danışma kurulu oluşturulmalıdır. Program danışma kurulunda sağlık sektörü temsilcilerine de yer verilmelidir. Müfredat güncelleme çalışmalarında danışma kurulunun tavsiyeleri alınarak verilen eğitim ile sektörün ihtiyaç duyduğu nitelikteki aday personel yetiştirilmelidir.

\section{Kaynaklar}

Akdaş, A., Sur, H., Şişman, N. ve Gemlik, N. (2008). İdari görevi bulunan hekimlerin sağl1k yönetimine bakış açıları. SD Sağlık Düşüncesi ve Tıp Kültürü̈ Dergisi, 2(5), 40-45.

Aktan, C. C. ve Vural, İ. (2016). Bilgi toplumu, yeni temel teknolojiler ve yeni ekonomi. Yeni Türkiye Dergisi, Bilim ve Teknoloji Ö̈zel Sayısı, 1(88), 1-37.

Alkan, R. M., Suiçmez, M., Aydınkal, M. ve Şahin, M. (2014). Meslek yüksekokullarındaki mevcut durum: sorunlar ve bazı çözüm önerileri. Yükseköğretim ve Bilim Dergisi, 4(3), 133-140.

Arslan, M. M. ve Bahadır, H. (2007). Bologna süreci ve Türkiye. Sosyal Bilimler Araştırmaları Dergisi, 2, 222-229.

Çelik, Z. (2012). Bologna süreci’nin avrupa yükseköğretim sistemi üzerine etkileri. Yükseköğretim ve Bilim Dergisi, 2(2), 100-105.

Dalğar, H., Tunç, H. ve Kaya, M. (2009). Bölgesel kalkınmada yükseköğretim kurumlarının rolü ve Bucak örneği. Mehmet Akif Ersoy Üniversitesi Sosyal Bilimler Enstitüsü Dergisi, 1(1), 39-50.

Elmas, M. (2012). Bologna süreci: uygulama veya uygulayamama. Yükseköğretim ve Bilim Dergisi, 2(3), 137-141.

Eichhorst, W., Rodriguez-Planas, N., Schmidl, R. and Zimmermann, K. (2012). A roadmap to vocational education and training systems around the world. IZA Discussion Paper No.7110, $1-43$.

Ersoy, K. ve Kavuncubaşı, Ş. (1995). Hastane yönetimi: nereden başlamalı. Toplum ve Hekim Dergisi, 10(69-70), 6-9.

Fişek, N. (1968). Sağlık yönetiminde modern eğilimler. 20.Milli Türk Tip Kongresi Zabıtları, İstanbul. https://www.ttb.org.tr/n_fisek/kitap_1/8.html adresinden 10.09.2020 tarihinde erişilmiştir.

Günay, D. ve Özer, M. (2016). Türkiye'de meslek yüksekokullarının 2000'li yıllardaki gelişimi ve mevcut zorluklar. Yüksekögretim ve Bilim Dergisi, 6(1), 1-12.

Güneş F. (2012). Bologna süreci ile yükseköğretimde öngörülen beceri ve yetkinlikler. Yükseköğretim ve Bilim Dergisi, 2(1), 1-9. 
Joffe, M. and MacKenzie-Davey, K. (2012). The problem of identity in hybrid managers: who are medical directors?. International Journal of Leadership in Public Services, 8(3), 161 - 174.

Kavuncubaşı, Ş. ve Yıldırım, S. (2015) Hastane ve sağlık kurumları yönetimi. Ankara: Siyasal Kitabevi.

Kaya, A. (2014). Meslek yüksekokulunda öğrenim gören öğrencilerin eğitim öğretim ve geleceğe yönelik düşünceleri. Ondokuz Mayıs Üniversitesi Eğitim Fakültesi Dergisi, 33(2), 349-356.

Kaya, R.R. ve Kaya, E. (2021). Yönetici Hekimlerin Melez İş Kimliği Deneyimleri Üzerine Nitel Bir Araştırma. Hacettepe Sağllk İdaresi Dergisi, 24(2), 275-294.

Kippist, L. and Fitzgerald, A. (2009). Organisational professional conflict and hybrid clinician managers. Journal of Health Organization and Management, 23(6), 642 - 655.

Mintzberg, H. (1979). The structuring of organisations. New Jersey: Prentice-Hall.

Sarvan, F. (1995). Hastane yönetimi eğitimi. Toplum ve Hekim Dergisi, 10, 69-70.

Spehar, I., Frich, J. C. and Kjekshus, L. E. (2014). Clinicians in management: a qualitative study of managers' use of influence strategies in hospitals. BMC Health Services Research, 14(1), 251.

Sur, H. (2017). Hastaneleri kim yönetsin? Doktorlar mı sağlık yönetimi uzmanları mı?. http://www.medikalnews.com/hastaneleri-kim-yonetsin-doktorlar-mi-saglik-yonetimiuzmanlari-mi/ adresinden 10.09.2020 tarihinde erişilmiştir.

Taştan, R. (2017). Türkiye'de önlisans sağlık meslekleri eğitimi 35 yaşında: sevgiçiçeği açan tarlalardan, portakal çiçeği kokan bereketli topraklara kısa bir sağlık meslekleri eğitimi tarihi yolculuğu. Marmara Sağlık Hizmetleri Dergisi, 1, 1-12.

Tengilimoğlu, D., Akbolat, M. ve Işsk, O. (2018). Sağlık işletmeleri yönetimi. Ankara: Nobel Yayıncilık.

Turner, B. S. (2011). Tıbbi gü̧ç ve toplumsal bilgi. (Ü. Tatlıcan, Çev.). Bursa: Sentez yayıncılık.

Türk Tabipleri Birliği (TTB). (1995). Kamu Hastaneleri Yönetim Sorunları, Grup Çalışması Sonuç Raporu. Ankara: Türk Tabipleri Birliği Merkez Konseyi.

Türkiye Yeterlilikler Veri Tabanı (2016-2019). Sağllk Kurumları İşletmeciliği ön lisans diploması. https://tyc.gov.tr/yeterlilik/saglik-kurumlari-isletmeciligi-on-lisans-diplomasi

TR00308315.html, adresinden 12.09.2020 tarihinde erişilmiştir.

Türkiye Yeterlilikler Veri Tabanı (2016-2019). Sağllk Kurumları İşletmeciliği ön lisans diploması. https://tyc.gov.tr/yeterlilik/saglik-kurumlari-isletmeciligi-on-lisans-diplomasi-

TR00305581.html, adresinden 12.09.2020 tarihinde erişilmiştir.

Wachter, B. (2004). The Bologna process: developments and prospects. European Journal of Education, 39 (3), 265-273.

Yılmaz, B. (2018). Türkiye'de bilgi ve belge yönetimi bölümleri ders programlarının arşivcilik ve belge yönetimi eğitimi açısından değerlendirilmesi. Bilgi Yönetimi Dergisi 1(1), 44-62.

Yükseköğretim Kurulu, (2019). https://yokatlas.yok.gov.tr/tercih-sihirbazi-t3.php adresinden 05.06.2020 tarihinde erişilmiştir. 
Yükseköğretim Kurulu, (2007). Türkiye’nin yüksek öğretim stratejisi. https://www.yok.gov.tr/Documents/Yayinlar/Yayinlarimiz/Turkiyenin-yuksekogretimstratejisi.pdf adresinden 09.10.2020 tarihinde erişilmiştir.

Yükseköğretim Kurulu, (2010). Türkiye yükseköğretim yeterlilikler çerçevesi. http://tyyc.yok.gov.tr/?pid=20, adresinden 09.10.2020 tarihinde erişilmiştir. 


\section{Extended Abstract}

\section{Introduction}

In today's conditions, the development and competitiveness of countries is realized with the intellectual capital they have. Due to the influence of the information age and globalization in which we are located, the ability to guide changes in many issues related to society can only be realized with the importance given to information and investment in education. Higher education institutions are institutions that play a critical role in the development of countries with their educational and training activities. The business world needs you have the necessary equipment, human resources, raising the quality of education improving vocational and technical education in vocational schools in the country to reduce the unemployment rate by providing a balance of education and employment and helps to contribute to the development of the country. "Vocational schools of Health Services", which provide education in various health fields for health services within vocational schools, have come to the fore in the field of employment in recent years. Developments in the field of Health have also revealed new health professions. Health technicians who are trained in different fields for these professions create value by increasing the quality of health service delivery with their medical and technical infrastructure.

Health is the most important phenomenon without a substitute for human life. Physicians, who are the most important element of health service delivery by using their medical knowledge, are in the position of "managing" health services with their professional weight. Health institutions are complex structures in which a large number of health professionals from different fields work together. Physicians who are not trained in management during medical education need professional health managers who have been trained in scientific management and management at the upper, middle and lower levels of Management in order to effectively and efficiently solve various problems that will occur in medical institutions. Health institutions management programs play an important role in the functioning of health institutions with the human resources that it will train with this mission. For this reason, the content of the training that will be provided in these programs is extremely important.

The inability of traditional educational understanding to adapt to social expectations, scientific developments and technology has led countries to review and change their educational systems. During the studies on this subject, the idea of creating a common higher education area in Europe arose. The Bologna declaration was signed with the participation of 29 European countries. Within the scope of this statement, the European Credit Transfer System (ECTS) has been implemented in order to increase the effectiveness of Europe in higher education and to ensure that the higher education degrees and diplomas of European countries are equivalent to each other. Today, the process continues with 47 member countries from many parts of the world. Turkey also wants to establish its place in the world in the field of Higher Education. Turkey is achieving success at all levels of the higher education system through its work in this direction.

Within the scope of this study, the variety of courses and ECTS values included in the current curricula of "Health Institutions management" associate degree programs in the vocational schools of State and foundation universities providing education in Turkey were examined. The aim of the study is to reveal the competencies of graduates trained in "health institutions management" programs in terms of the courses they take.

\section{Method}

Research is a quantitative study that uses secondary data. In this research, the YÖKATLAS associate degree database, which was created by the Higher Education Council of Turkey (YÖK), was used. Associate degree program in management of Health Institutions was searched through the YÖKATLAS database, and research was conducted through universities and programs that receive students as of 2019.

The universe of the study consists of Health Institutions management programs in universities in Turkey. An attempt was made to reach the entire universe without selecting a specific sample. During the screening, 49 universities were identified, including 34 public and 14 foundations, which have a health institutions management program in Turkey. Some universities could not be included in 
the scope of the research due to lack of access to Bologna information. Also open teaching programs are not included in sampling. Of the universities that have multiple health institutions management programs, only one program has been included in the sampling. As a result of the qualifiers, research was conducted on the Bologna systems of 26 public and 10 foundation universities. The names, hours, ECTS, periods, compulsory/elective status and theoretical/practical course diversity of the courses included in the curricula of health institutions management programs were examined. The data obtained was transferred to the database created in Excel program and the frequency distributions were evaluated. In addition, the courses identified within the scope of the research were grouped among themselves according to their subjects, content and scope, and the scope of the courses of Health Institutions Management Programs was tried to be determined. In this method, it is aimed to determine the theoretical competencies obtained by graduates of the health institutions management program and to evaluate the employment opportunities.

\section{Findings}

It has been observed that the total number of courses of health institutions management programs is in a very wide range from 24 to 70 . The least courses are located at Üsküdar University (24), while the most courses are located at Istanbul Kültür University (70). The distribution of compulsory/elective courses is an important point in the units providing associate degree level education. In recent years, the concept that the number of elective courses is equal to or higher than the number of compulsory courses has prevailed in Turkey. This understanding is supported in line with YÖK's "Bologna Process" Work. Foundation universities (55\%) offer more elective courses to students than public universities (41.67\%). The proportion of elective courses in 10 universities, including 5 state universities and 5 foundation universities, is over $50 \%$. In general, the number of compulsory courses was higher in the health institutions management programs of universities than in the electives. In addition, it has been found that there are significant differences between the programs in this regard.

In the study, it was found that there were 196 courses in the curricula of Health Institutions management programs. Although the content and scope of many of the courses are the same, their names are different. This indicates that there is no standardization in the curricula of Health Institutions management programs. In terms of the scope and content of the courses in question; "health sciences, law, mathematics, economics and finance, sociology, management and strategy, communication, technology, research methods, professional practice, art, vocational english, physical education, psychology, business, marketing, quality, documentation including" in 18 categories are combined. The distribution of the courses given, mainly in the fields of Health, Management, Economics and law, shows that students in the Associate Degree Programs of Health Institutions in Turkey are trained by taking courses in 18 different fields. And this gives an idea of the competencies of the students who will graduate in terms of the courses they take.

\section{Results, Discussion and Recommendations}

Students who graduate from the health institutions management program are expected to serve as administrative staff in family health centers, pharmacies and medical enterprises, especially in hospitals. In this context, students; basic health information, medical documentation, Hospital Information Systems and medical terminology, as well as management, Basic Business, Accounting, Finance, Marketing, Public Relations, Human Resources, sociology, psychology offers courses in the fields of. It is seen that students are trained to be administrative staff in the health sector with information about the provision of Health Services, which is a multidisciplinary field. Therefore, graduates of health institutions management can be assigned as administrative staff in health installations. In this direction, it is recommended to evaluate graduates of Health Institutions Management in human resources planning in both public and private health installations.

The tables in the study are a guide that shows the names of the courses in the health institutions management programs, their hours as theoretical or practical, their mandatory or optional status, ECTS information and what period they are involved in. With this feature, it is thought that it will be an exemplary resource in curriculum development and change studies. It has been observed 
that there is no standard in the curriculum of the health institutions management program. It is necessary to provide a standard for naming courses with similar content with workshops that will be conducted by experts in the field.

One of the most important tasks of vocational colleges is to train qualified personnel needed by the sector it addresses. In terms of harmonizing the expectations of the sector with university education in the curriculum update studies, opinions should be taken from the health sector representatives. In this context, a program advisory board should be established in accordance with the proposal of the Higher Education Quality Board. Health sector representatives should be included in the program advisory board. In curriculum update studies, the recommendations of the program advisory board should be taken. Curricula to be created in this way will contribute to the training of candidate personnel in the competence required by the sector. 